\title{
PENGARUH KECERDASAN INTELEKTUAL, KECERDASAN EMOSIONAL, DAN KECERDASAN SPIRITUAL TERHADAP PEMAHAMAN MATA KULIAH PENGANTAR AKUNTANSI
} (Studi Pada Mahasiswa Jurusan Akuntansi Universitas Muhammadiyah Bengkulu)

\author{
${ }^{1)}$ Erwin Febriansyah ${ }^{2)}$; Fraternesi ${ }^{3)}$ Anina Safitri \\ 1) Department of Accountancy, Faculty of Economic and Business, \\ Universitas Muhammadiyah Bengkulu \\ 2) Department of Accountancy, Faculty of Economic and Business, Universitas \\ Muhammadiyah Bengkulu \\ 3) Department of Accountancy, Faculty of Economic and Business, Universitas \\ Muhammadiyah Bengkulu \\ Email: ${ }^{1)}$ erwinfebriansyah@gmail.com; ${ }^{2)}$ fraternesi@gmail.com $^{3)}$ \\ aninasafitri336@yahoo.com
}

\begin{abstract}
How to Cite :
Febriansyah, E. (2020). PENGARUH KECERDASAN INTELEKTUAL, KECERDASAN EMOSIONAL, DAN KECERDASAN SPRITUAL TERHADAP PEMAHAMAN MATA KULIAH PENGANTAR AKUNTANSI (Studi Pada Mahasiiswa Jurusan Akuntansi Universitas Muhammadiyah Bengkulu).https://doi.org/10.37676/ekombis.v8i2
\end{abstract}

\section{ARTICLE HISTORY}

Received [28 06 2020]

Revised [16 07 2020]

Accepted [29 07 2020]

\section{KEYWORDS}

Intellectual Intelligence,

Emotional Intelligence,

Spiritual Intelligence,

Understanding

of

Introductory Accounting

Courses

This is an open access article under the $\underline{C C-B Y-S A}$ license

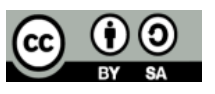

\section{ABSTRAK}

Penelitian ini bertujuan untuk mengetahui secara empiris pengaruh kecerdasan intelektual, kecerdasan emosional dan kecerdasan spiritual terhadap pemahaman mata kuliah pengantar akuntansi studi pada mahasiswa akuntansi universitas muhammadiyah bengkulu. Metode pengambilan sampel dalam penelitian ini menggunakan sample random sampling. Sampel yang digunakan dalam penelitian ini adalah mahasiswa jurusan akuntansi universitas muhammadiyah bengkulu semester 4 dan 6 yang diambil secara random sampling berjumlah 82 mahasiswa. Alat uji yang digunakan untuk hipotesis adalah uji regresi logistik dan kemudian hasil uji tersebut di interprestasikan. Penelitian ini diharapkan dapat memberikan pengetahuan yang mendasar bagi perguruan tinggi dalam rangka meningkatkan pemahaman mata kuliah pengantar akuntansi fakultas ekonomi akuntansi universitas muhammadiyah bengkulu. Hasil penelitian menggunakan analisis regresi logistik menunjukkan kecerdasan intelektual, kecerdasan emosional, dan kecerdasan spiritual terhadap pemahaman mata kuliah pengantar akuntansi pada mahasiswa akuntansi universitas muhammadiyah bengkulu.

160 | Erwin Febriansyah; Fraternesi; Anina Safitri; Pengaruh Kecerdasan Intelektual, Kecerdasan Emosional, ... 


\section{ABSTRACT}

The aim of this study is to determine empirically the effect of intellectual intelligence, emotional intelligence and spiritual intelligence on the understanding of introductory accounting courses in accounting students at the Muhammadiyah University of Bengkulu.The sampling method in this research used random sampling. The samplewas students majoring in accounting at Muhammadiyah University of Bengkulu, semester 4 and 6, taken by random sampling totaling 82 students. Test equipment used for the hypothesis were a logistic regression test, and then the test results were interpreted. This research is expected to provide fundamental knowledge for tertiary institutions in order to improve understanding of introductory courses in accounting, economics faculty of Muhammadiyah University of Bengkulu.The results using logistic regression analysis showed that intellectual intelligence, emotional intelligence, and spiritual intelligence on the understanding of introductory accounting courses in accounting students at the Muhammadiyah University of Bengkulu.

\section{PENDAHULUAN}

Mata kuliah di perkenalkan dan diperdalam lagi pada saat mahasiswa resmi terdaftar di perguruan tinggi negeri maupun swasta dengan tujuan nantinya dapat menjadi akuntan yang ahli dibidangnya. Perguruan tinggi merupakan tempat untuk mahasiwa memperoleh seluk beluk mengenai akuntansi di sesuaikan dengan kurikulum setiap perguruan tinggi dengan harapan nantinya dapat menjadi akuntan profesional dengan syarat sistem pendidikan yang di tawarkan selain sesuai dengan tuntuan dunia kerja. ini merupakan kekhawatiran dunia industri adanya ketidakkonsistennya hasil lulusnya di karenakan ketidakmampuan perguruan tinggi menjadikan mahasiswa tersebut paham dan menguasai akuntansi di tambah lagi kecerdasan emosional dan kecerdasan spiritual yang di miliki juga rendah.

Dalam aktivitas perkuliahan konsentrasi penuh maka mahasiswa akan memahami dan akan mengerti terhadap mata kuliah yang diajarkan. Akan tetapi dalam kenyataan keseharian masih banyak kurangnya konsentrasi belajar mahasiswa di kelas. Faktor dari permasalahan tersebut kurangnya manajemen waktu, kondisi kesehatan, kurang minat terhadap mata kulia, adanya masalah pribadi atau masalah keluarga, dan cara penyampaian materi oleh dosen, karena adanya faktor tersebut pasti juga adanya dampak negatif untuk mahasiswa sendiri.Kecerdasan manusia dapat dilihat dari tiga kompunen utama. Pertama, kemampuan untuk mengarakan pikiran dan tindakan. Kedua, kemampuan untuk mengubah arah pikiran atau tindakan. Ketiga, kemampuan untuk mengkritisi kemampuan dan tindakan sendiri. (Yaumi \& Ibrahim, 2013: 10).

Berdasarkan fakta dan harapan tersebut tampak masalah berupa masih rendahnya pemahaman konsep dasar akuntansi keuangan diperguruan tinggi. Dengan demikian tingkat pendidikan diperguruan tinggi masih menunjukan hasil yang tidak sesuai dengan yang diharapkan, padahal proses belajar mengajar pada pendidikan tinggi akuntansi hendaknya dapat mentransformasikan peserta didik menjadi lulusan yang lebih utuh sebagai manusia.

Penelitian ini merupakan replikasi dari penelitian Muhammad rizal satria (2017) dimana penelitian sebelumnya meneliti tentang Pengaruh kecerdasan emosional terhadap tingkat pemahaman akuntansi pada mahasiswa akuntansi di Kota Bandung, dan menyarankan 
menganalisis terhadap pemahaman akuntansi menggunakan variabel lainnya yang memiliki pengaruh yang lebih besar terhadap pemahaman akuntansi. Dari hasil penelitian ini dapat disimpulkan bahwa terdapat pengaruh signifikan antara variabel kecerdasan emosional terhadap pemahaman akuntansi. Variabel kecerdasan emosional memberikan kontribusi pengaruh sebesar $22,5 \%$ terhadap pemahaman akuntansi, sedangkan sisanya 77,5\% dijelaskan oleh faktor-faktor lain yang tidak diteliti.

Pada penelitian yang akan penuilis lakukan menggunakan satu variabel yang sama dengan penelitian terdahulu yaitu kecerdasaan emosional dan dua variabel baru yaitu kecerdasan intelektual dan kecerdasan spiritual terhadap pemahaman mata kuliah pengantar akuntansi.

\section{LANDASAN TEORI}

\section{Kecerdasan intelektual (IQ)}

Kecerdasan intelektual adalah kemampuan untuk mengarahkan pikiran atau tindakan, kemampuan untuk mengubah arah tindakan jika tindakan sudah dilakukan dan kemampuan untuk mengkritik diri sendiri. Kecerdasan intelektual ini adalah hal-hal yang berada di luar manusia seperti kimia, matematika, bahasa, fisika, dan lain-lain. Dengan demikian, kecerdasan intelektual hanya memberikan sedikit indikasi mengenai taraf kecerdasan manusia dan tidak menggambarkan kecerdasan seseorang secara keseluruhan, dapat dikatakan pula bahwa kecerdasan intelektual adalah ukuran kemampuan intelektual, analisis, logika, dari manusia yang merupakan kecerdasan otak untuk menerimah, menyimpan, dan mengolah informasi menjadi fakta (Dadang, 2010 : 9).

Tingkat kecerdasan manusia yang ditentukan secara metodik oleh IQ (kecerdasan intelektual) memegang peranan penting dalam menentukan kesuksesan seseorang dalam belajar. Menurut penyelidikannya IQ dapat ditentutkan sekitar umur 3 tahun. Daya tangkap sangat dipengaruhi oleh garis keturunan atau gen. Daya tangkap ini takkan berubah sampai seseorang dewasa, kecuali bila ada sebab kemunduran fungsi otak seperti penuaan dan kecelakaan

karena setelah otak mencapai kemasakan, tidak terjadi perkembangan lagi bahkan pada titik tertentu akan terjadi penurunan kemampuan.

\section{Kecerdasan Emosional (EQ)}

Kecedasan emosional (EQ) adalah kemampuan untuk mendeteksi dan mengelolah emosi diri sendiri maupun orang lain. Manusia sangat berpengaruh dengan suasana perasaannya dalam melakukan kegiatan. Karena itu emosi memiliki peran penting dalam mendukung keberhasilan. Kecerdasan emosional ini berhubungan erat dengan kecerdasan majemuk, yang diusung oleh Gardner. Kedua kecerdasan yang di sebut Gardner sebagai kecerdasan pribadi tersebut merupakan kemampuan untuk memahami orang (Dadang, $2010: 15$ ).

Kecerdasan emosional membuat seseorang menjadi menyadari sisi kemanusiaannya sehingga membuat lebih manusiawi. Berbagai bukti yang pengelolaan emosinya baik (mengetahui dan menangani perasaan sendiri, mampu membaca dan menghadapi orang lain dengan efektif) memiliki kelebihan dalam hubungan antar manusia dan organisasi. Sebaliknya orang yang tidak dapat mengendalikan emosinya akan mengalami pertarungan yang dapat merampas kemampuan mereka untuk berkonsentrasi pada karier atau pekerjaan ataupun untuk memiliki pikiran yang jernih (Dadang, $2010: 16$ ).

Dalam hal ini peran penting kecerdasan emosional mencakup pengendalian diri, semangat, dan ketekunan, serta kemampuan untuk memotivasi diri sendiri dan bertahan dalam menghadapi frustasi, kesanggupan untuk mengendalikan dorongan hati dan emosi tidak melebih-lebihkan kesenangan, mengatur suasana hati dan menjaga agar beban tidak stress tidak melumpuhkan kemampuan berpikir, untuk membaca perasaan terdalam orang lain (empati) dan berdoa untuk memelihara hubungan dengan sebaik-baiknya kemampuan untuk menyelesaikan konflik, serta untuk memimpin.

162 | Erwin Febriansyah; Fraternesi; Anina Safitri; Pengaruh Kecerdasan Intelektual, Kecerdasan Emosional, ... 


\section{Kecerdasan Spiritual (SQ)}

Kecerdasan spiritual (SQ) adalah pemikiran yang terilhami kecerdasan ini di ilhami oleh dorongan dan efektifitas, keberadaan atau hidup ilahi yang yang mempersatukan kita dengan makhluk hidup ciptaan Allah SWT. Sebagai sumber utama kegairahan yang memiliki exstensi tanpa asal, kekal, abadi, lengkap pada diri dan daya kreatifnya. Kecerdasan spiritual ini melibatkan kemampuan untuk menghidupkan kebenaran yang paling dalam. Yang berarti mewujudkan hal terbaik, utuh dan paling manusiawi dalam batin (Yaumi \& Ibrahim, $2013: 22$ ).

Landasan yang diperlukan untuk memfungsikan kecerdasan intelektual (IQ) secara efektif. Bahkan SQ merupakan kecerdasan tertinggi, karena SQ merupakan landasan dan sumber dari kecerdasan yang lain. Selanjutnya, tugas setiap oranglah untuk mengenali potensi masingmasing sekaligus menggosoknya hingga berkilau dengan tekad yang besar dan menggunakannya untuk memperoleh kebahagiaan abadi.

Individu yang cerdas secara spiritual melihat kehidupan ini lebih agung dan sakral, menjalaninya sebagai sebuah panggilan (vocation) untuk melakukan sesuatu yang unik, menemukan ekstase-ekstase kehidupannya dari pelayanan kepada gagasan-gagasan yang bukan pemuasan diri sendiri, melainkan kepada tujuan luhur dan agung, yang bahkan sering keluar dari dunia ini, bersifat abadi dan eksatologis. Kehidupan menjadi lebih sebagai instrument ketimbang tujuan akhir.

Tanda-tanda dari kecerdasan spiritual yang telah berkembang dengan baik. Kemampuan bersikap fleksibel (adaptif secara spontan dan aktif), kemampuan untuk menghadapi dan memanfaatkan penderitaan, kemampuan untuk menghadapi dan melampaui rasa sakit, kualitas hidup yang ilhami oleh visi dan nilai, keengganan untuk menyebabkan kerugian yang tidak perlu ( Yaumi \& Ibrahim, $2013: 23$ ).

Dari beberapa tanda-tanda orang yang mempunyai kecerdasan spiritual tersebut dapat kita simpulkan bahwa orang yang mempunyai kecerdasan spiritual baik merupakan orang yang pribadinya aktif mampu beradaptasi dengan lingkungan ia berada, mandiri, mempunyai pandangan yang luas atas banyak hal, tujuan hidup yang dimiliki bersumber dari agama.

Seorang yang tinggi SQ-nya cenderung menjadi seorang pemimpin yang penuh pengabdian yaitu seorang yang bertanggung jawab untuk membawakan visi dan nilai yang lebih tinggi terhadap orang lain, ia dapat memberikan inspirasi terhadap orang lain. Setiap pribadi yang menjadi mandiri, proaktif, berpusat pada prinsip yang benar, digerakkan oleh nilai dan mampu mengaplikasikan dengan integritas, maka ia pun dapat membangun hubungan saling tergantung, kaya, langgeng, dan sangat produktif dengan orang lain.

Kecerdasan spritual yang tinggi memiliki prinsip dan visi yang kuat. Prinsip adalah kebenaran yang dalam dan mendasar ia sebagai pedoman berperilaku yang mempunyai nilai yang langgeng dan produktif. Prinsip manusia secara jelas tidak akan berubah, yang berubah adalah cara kita mengerti dan melihat prinsip tersebut. Semakin banyak kita tahu mengenai prinsip yang benar semakin besar kebebasan pribadi kita untuk bertindak dengan bijaksana.

\section{Pemahaman Mata Kuliah Pengantar Akuntansi}

pemahaman akuntansi mahasiswa dinyatakan dengan seberapa mengerti seorang mahasiswa terhadap apa yang sudah dipelajari yang dalam konteks ini mengacu pada mata kuliah akuntansi dan Indeks Prestasi Kumulatif (IPK). Tanda seorang mahasiswa memahami akuntansi tidak hanya ditujukan dari nilai-nilai yang didapatkannya dalam mata kuliah tetapi juga apabila mahasiswa tersebut mengerti dan dapat menguasai konsep-konsep yang terkait dengan mata kuliah (Paskah $2010: 10$ ). 


\section{METODE PENELITIAN}

\section{Metode Analisis}

Metode analisis yang digunakan dalam penelitian yaitu metode analisis regresi logistik. Agar hasilnya bisa diinterpretasikan dalam bentuk angka digunakan alat bantu statistik yaitu SPSS (Statiscal Package for Social Science) ( Rambat \& Ridho, 2015 : 168). Analisis ini digunakan untuk menentukan hubungan antara kecerdasan intelektual, emosional, spiritual terhadap pemahaman mata kuliah pengantar akuntansi sebagai variabel dependen.

Dalam penelitian ini variabel dependen (pemahaman mata kuliah pengantar akuntansi) menggunakan variabel dummy yaitu jika nilai ketercapaian responden $\mathrm{A}, \mathrm{B}$, atau $\mathrm{C}$ maka dikatagorikan dengan angka 1 (satu) yang berarti lulus dan jika nilai ketercapaian responden D atau E maka dikatagorikan dengan angka 0 (nol) berarti tidak lulus ( Rambat \& Ridho, 2015 : 168). Dengan memiliki persamaan sebagai berikut.

$$
\begin{aligned}
& \log (\mathrm{P} / 1-\mathrm{p})=\alpha+\beta 1 \mathrm{X} 1+\beta 2 \mathrm{X} 2+\beta 3 \mathrm{X} 3 \ldots \ldots \ldots \ldots \\
& \log (\mathrm{P} / 1-\mathrm{p})=\alpha+\mathrm{b} 1 \mathrm{X} 1+\beta 2 \mathrm{X} 2+\beta 3 \mathrm{X} 3+\beta 4 \mathrm{X} 4 \ldots \\
& \log (\mathrm{P} / 1-\mathrm{p})=\alpha+\beta 1 \mathrm{X} 1 * \mathrm{X} 4+\beta 2 \mathrm{X} 2 * \mathrm{X} 4+\beta 3 \mathrm{X} 3 * \mathrm{X}
\end{aligned}
$$

Dalam penelitian ini variabel dependen (pemahaman mata kuliah akuntansi) menggunakan variabel dummy yaitu jika nilai ketercapaian responden A, B, maka dikatagorikan dengan angka 1 (satu) yang berarti lulus dan jika nilai ketercapaian responden C, D atau E maka dikatagorikan dengan angka 0 (nol) berarti tidak lulus.

\section{Pembahasan}

\section{HASIL DAN PEMBAHASAN}

Penelitian ini dilakukan untuk mengetahui pengaruh kecerdasan intelektual, kecerdasan emosional, dan kecerdasan spiritual terhadap pemahaman mata kuliah pengantar akuntansi (studi pada mahasiswa jurusan akuntansi Universitas Muhammadiyah Bengkulu)".

\section{Hasil Uji Hipotesis penelitian Regresi Logistik}

Berikut ini ada beberapa tabel dari hasil uji SPSS (Statiscal Package for Social Science) beserta penjelasan yang akan di gambarkan.

\section{Tabel 2}

\section{Jumlah Pengamatan}

Case Processing Summary

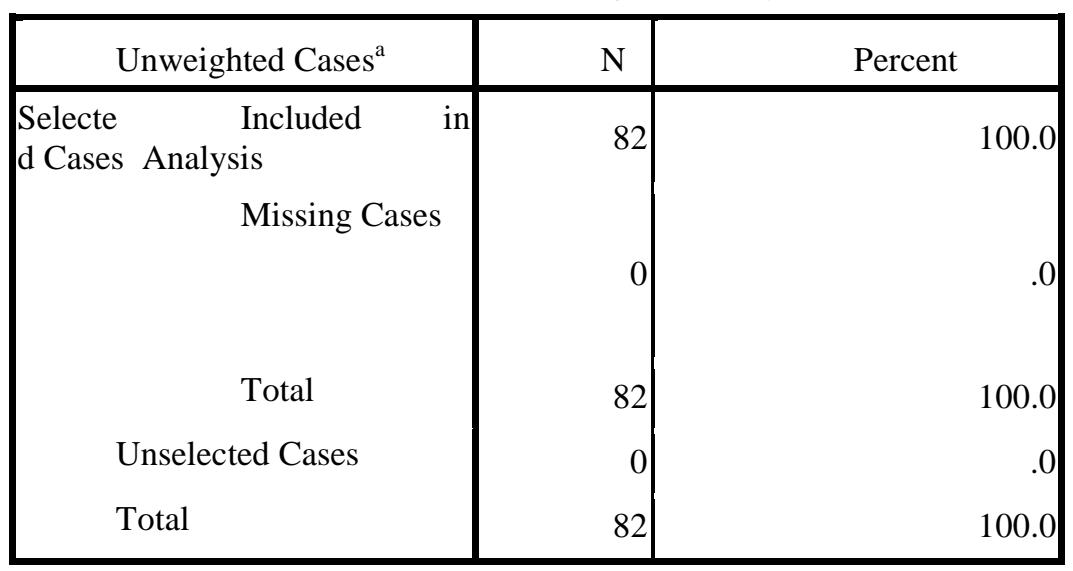

memberikan informasi tentang jumlah kasus yang dianalisis dalam penelitian ini. Ada sebanyak 82 kasus yang di analisis yang di tunjukan pada baris included in analysis pada baris missing cases $=0$. Sehingga dalam penelitian ini tidak ada kasus yang terlewatkan (missing). 
Maka disitu menunjukan dan menjelaskan bahwa seluruh kasus atau case ternyata teramati semua sebanyak 82 sampel, artinya tidak ada sampel yang hilang atau missing.

\section{Menilai keseluruhan model (Overall Model fit)}

Uji Overal Model fit atau uji keseluruhan model ini adalah untuk menguji variabel independen di dalam regresi logistik secara serentak atau simultan mempengaruhi variabel dependen. Uji Overal model fit ini dihitung dari perbedaan nilai -2LL antara model dengan hanya terdiri dari konstanta dan model yang diestimasi terdiri dari konstanta dan variabel independen Uji -2LL mengikuti distribusi chi square dengan derajat kebebasan ( degree off frendom ) akan ditampilkan pada tabel $4.3-4.5$.

Tabel 3. Nilai -2LL yang Terdiri Dari Konstanta

\begin{tabular}{|c|c|c|c|}
\hline \multicolumn{4}{|c|}{ Iteration History $^{\mathrm{a}, \mathrm{b}, \mathrm{c}}$} \\
\hline \multirow[b]{2}{*}{ Iteration } & & \multirow{2}{*}{$\begin{array}{l}-2 \text { Log } \\
\text { likelihood }\end{array}$} & Coefficients \\
\hline & & & Constant \\
\hline \multirow[t]{4}{*}{ Step 0} & 1 & 84.107 & 1.171 \\
\hline & 2 & 83.703 & 1.333 \\
\hline & 3 & 83.702 & 1.341 \\
\hline & 4 & 83.702 & 1.341 \\
\hline
\end{tabular}

Sumber : olah data spss versi 16, 2019

a. Constant is included in the model.

b. Initial -2 Log Likelihood: 83,702 less than ,001.

c. Estimation terminated at iteration number 4 because parameter estimates changed by

Tabel 4. Nilai -2ll yang Terdiri dari Konstanta dan Variabel Bebas Iteration History ${ }^{\mathrm{a}, \mathrm{b}, \mathrm{c}, \mathrm{d}}$

\begin{tabular}{|c|c|c|c|c|c|}
\hline \multirow[b]{2}{*}{ Iteration } & \multirow{2}{*}{$\begin{array}{l}-2 \log \\
\text { likelihood }\end{array}$} & \multicolumn{4}{|c|}{ Coefficients } \\
\hline & & Constant & $\mathrm{KI}$ & $\mathrm{KE}$ & $\mathrm{KS}$ \\
\hline
\end{tabular}

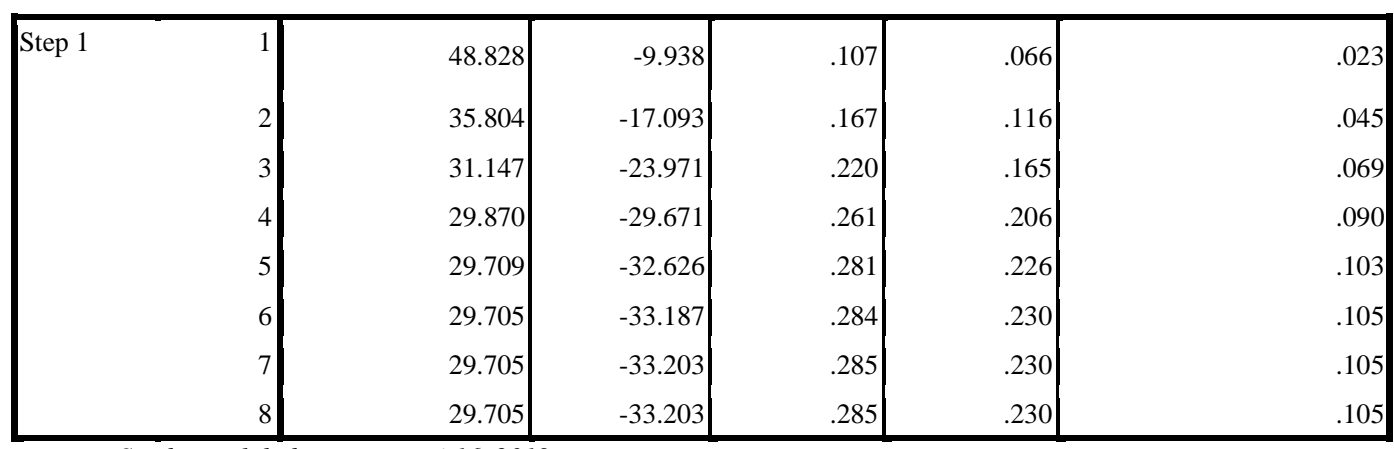

Sumber : olah data spss versi 16, 2019

a.marge : enter

b. Constant is included in the model.

c. Initial -2 Log Likelihood: 83,702 


\section{Uji Wald}

Pada uji wald uji hipotesis akan dilakukan secara individual atau secara persial. Pengujian hipotesis dilakukan dengan cara memasukan satu persatu variabel pengaruh kecerdasan intelektual, kecerdasan emosional, dan kecerdasan spiritual terhadap pemahaman mata kuliah pengantar akuntansi. Pengujian ini di lakukan untuk mengetahui pengaruh masingmasing variabel independen terhadap variabel dependen.

Tabel 5. Uji Wald

Variables in the Equation

\begin{tabular}{|c|c|c|c|c|c|c|}
\hline & B & S.E. & $\mathrm{d}^{\text {Wal }}$ & Df & Sig. & B) $\operatorname{Exp(}$ \\
\hline Step $1^{\mathrm{a}}$ & & .092 & $\begin{array}{r}9.52 \\
5\end{array}$ & 1 & .002 & 1.329 \\
\hline $\mathrm{E}$ & & .073 & $\begin{array}{r}10.0 \\
22\end{array}$ & 1 & .002 & 1.259 \\
\hline$S$ & .105 & .062 & $\begin{array}{r}2.89 \\
6\end{array}$ & 1 & .089 & 1.111 \\
\hline $\begin{array}{l}\text { onst } \\
\text { ant }\end{array}$ & 33.203 & 9.795 & $\begin{array}{r}11.4 \\
92\end{array}$ & 1 & .001 & .000 \\
\hline
\end{tabular}

Sumber : olah data spss versi 16, 2019

a. Variable(s) entered on step 1: KI, KE, KS.

Dalam pembahasan disini penulis akan menjelaskan pengaruh hubungan antar variabel dependen dan independen yang akan dibuat sesuai dengan hasil yang telah dijelaskan sebelumnya.

Pengaruh Kecerdasan Intelektual Terhadap Pemahaman Mata Kuliah Pengantar akuntansi (Studi Pada Mahasiswa Akuntansi Universitas Muhammadiyah Bengkulu).

Berdasarkan tabel 4.6 maka dapat disimpulkan bahwa variabel kecerdasan intelektual (X1) dengan nilai signifikansi 0,02, ini berarti bahwa kecerdasan intelektual signifikan dengan ketentuan yaitu kurang dari $0,05(5 \%)$ pada pemahaman mata kuliah pengantar akuntansi, menyatahkan bahwa kecerdasan intelektual berpengaruh secara parsial terhadap pemahaman mata kuliah pengantar akuntansi. Jadi kesimpulan dari hipotesis satu (H1) adalah diterimah yaitu kecerdasan intelektual secara parsial berpengaruh terhadap pemahaman mata kuliah pengantar akuntansi.

Penerimaan hipotesis ini menunjukan bahwa kecerdasan intelektual yang dimiliki oleh mahasiswa jurusan akuntansi universitas Muhammadiyah Bengkulu, ikut mempengaruhi keberhasilan mahasiswa dalam mencapai hasil pemahaman mata kuliah pengantar akuntansi. Mahasiswa ini adalah mahasiwa yang memliki nilai tinggi dalam mata kuliah pengantar akuntansi. Hal ini sesuai dengan teori mencerdaskan IQ, SQ, EQ yang berisi bahwah kecerdasan intelektual berkaitan dengan proses berpikir dengan lebih menggunakan otak dapat mempengaruhi pemahaman belajar dan prestasi belajar .

Selain itu kecerdasan intelektual adalah kemampuan untuk mengarahkan pikiran atau tindakan, kemampuan untuk mengubah arah tindakan jika tindakan sudah dilakukan dan kemampuan untuk mengkritik diri sendiri. Kecerdasan intelektual ini adalah hal-hal yang berada di luar manusia seperti kimia, matematika, bahasa, fisika, dan lain-lain, termasuk juga mata

166 | Erwin Febriansyah; Fraternesi; Anina Safitri; Pengaruh Kecerdasan Intelektual, Kecerdasan Emosional, ... 
kuliah pengantar akuntansi. Dengan demikian, kecerdasan intelektual hanya memberikan sedikit indikasi mengenai taraf kecerdasan manusia dan tidak menggambarkan kecerdasan seseorang secara keseluruhan, dapat dikatakan pula bahwa kecerdasan intelektual adalah ukuran kemampuan intelektual, analisis, logika, dari manusia yang merupakan kecerdasan otak untuk menerimah, menyimpan, dan mengolah informasi menjadi fakta (Dadang, $2010: 9$ ).

\section{Pengaruh Kecerdasan Emosional Terhadap Pemahaman Mata Kuliah Pengantar akuntansi (Studi Pada Mahasiswa Akuntansi Universitas Muhammadiyah Bengkulu).}

Berdasarkan tabel 4.6 secara parsial menunjukan bahwa hasil signifikansi variabel kecerdasan emosional (X2) signifikan, hal ini dibuktikan dari nilai signifikansi (uji wald) yaitu 0,02 yang berarti lebih kecil dari ketentuan signifikan 0,05 (5\%). Maka dapat disimpulkan bahwa variabel kecerdasan emosional (X2) ini berpengaruh terhadap pemahaman mata kuliah pengantar akuntansi. Hal ini menunjukan bahwa hipotesis kedua (H2) diterimah dalam penelitian ini.

Maka dapat dijelaskan semakin tinggi kecerdasan emosional seorang mahasiswa maka akan semakin tinggi pula pemahaman terhadap mata kuliah pengantar akuntansi. Teori ini juga didukung sesuai dengan pengertian kecerdasan Emosional yaitu, membuat seseorang menjadi menyadari sisi kemanusiaannya sehingga membuat lebih manusiawi. Berbagai bukti yang pengelolaan emosinya baik (mengetahui dan menangani perasaan sendiri, mampu membaca dan menghadapi orang lain dengan efektif) memiliki kelebihan dalam hubungan antar manusia dan organisasi. Sebaliknya orang yang tidak dapat mengendalikan emosinya akan mengalami pertarungan yang dapat merampas kemampuan mereka untuk berkonsentrasi pada karier atau pekerjaan ataupun untuk memiliki pikiran yang jernih (Dadang, $2010: 16$ ).

Dalam hal ini peran penting kecerdasan emosional mencakup pengendalian diri, semangat, dan ketekunan, serta kemampuan untuk memotivasi diri sendiri dan bertahan dalam menghadapi frustasi, kesanggupan untuk mengendalikan dorongan hati dan emosi tidak melebih-lebihkan kesenangan, mengatur suasana hati dan menjaga agar beban tidak stress tidak melumpuhkan kemampuan berpikir, untuk membaca perasaan terdalam orang lain (empati) dan berdoa untuk memelihara hubungan dengan sebaik-baiknya kemampuan untuk menyelesaikan konflik, serta untuk memimpin. Begitu juga dalam pengendalian pemahaman belajar mata kuliah pengantar akuntansi.

\section{Pengaruh Kecerdasan Spiritual Terhadap Pemahaman Mata Kuliah Pengantar akuntansi (Studi Pada Mahasiswa Akuntansi Universitas Muhammadiyah Bengkulu).}

Berdasarkan hasil output SPSS pada tabel 4.6 maka dapat disimpulkan bahwa variabel kecerdasan spiritual (X3) dengan nilai signifikansi 0,089, ini berarti bahwa kecerdasan spiritual tidak signifikan pada tingkat signifikan $1 \%(0,01)$ dan $5 \%(0,05)$ tetapi pada tingkat signifikansi $10 \%(0,10)$ maka variabel kecerdasan spiritual mengalami signifikan. Probabilitas signifikansi yang lebih besar dari nilai $p=0,10(0,089<0,10)$, menyatakan bahwa kecerdasan intelektual berpengaruh secara parsial terhadap pemahaman mata kuliah pengantar akuntansi.

Jadi kesimpulan dari hipotesis ketiga (H3) adalah diterimah yaitu kecerdasan spiritual secara parsial berpengaruh terhadap pemahaman mata kuliah pengantar akuntansi.

Penerimaan hipotesis ini menunjukan bahwa kecerdasan spiritual yang dimiliki oleh mahasiswa jurusan akuntansi universitas muhammadiyah bengkulu, ikut mempengaruhi keberhasilan dalam nilai pemahaman mata kuliah pengantar akuntansi yang baik. Oleh karena itu semakin tinggi kecerdasan spiritual yang dimiliki mahasiswa maka akan semakin berpengaruh terhadap pemahaman mata kuliah pengantar akuntansi. Kecerdasan spiritual merupakan landasan yang diperlukan untuk memfungsikan kecerdasan intelektual secara efektif. Bahkan kecerdasan spiritual merupakan kecerdasan tertinggi, karena kecerdasan spiritual merupakan landasan dan sumber dari kecerdasan yang lain. Selanjutnya, tugas setiap oranglah 
untuk mengenali potensi masing-masing sekaligus menggosoknya hingga berkilau dengan tekad yang besar dan menggunakannya untuk memperoleh kebahagiaan abadi (Dadang, $2010: 16$ ).

Kecerdasan spiritual adalah pemikiran yang terilhami kecerdasan ini di ilhami oleh dorongan dan efektifitas, keberadaan atau hidup ilahi yang yang mempersatukan kita dengan makhluk hidup ciptaan Allah SWT. Sebagai sumber utama kegairahan yang memiliki exstensi tanpa asal, kekal, abadi, lengkap pada diri dan daya kreatifnya. Kecerdasan spiritual ini melibatkan kemampuan untuk menghidupkan kebenaran yang paling dalam. Yang berarti mewujudkan hal terbaik, utuh dan paling manusiawi dalam batin.

\section{Kesimpulan}

\section{KESIMPULAN DAN SARAN}

Penelitian ini di lakukan untuk mengetahui pengaruh kecerdasan intelektual, kecerdasan emosional, dan kecerdasan spiritual terhadap pemahaman mata kuliah pengantar akuntansi ( studi pada mahasiswa jurusan akuntansi Universitas Muhammadiyah Bengkulu). Responden dalam penelitian ini berjumlah 82 mahasiswa semester 4 dan 6. Berdasarkan pada data yang telah dikumpulkan dan pada hasil pengujian yang telah di lakukan terhadap permasalahan dengan menggunakan alat bantu SPSS dengan regresi logistik, maka dapat diambil kesimpulan sebagai berikut :

1. Hipotesis pertama kecerdasan intelektual berpengaruh secara parsial terhadap pemahaman mata kuliah pengantar akuntansi. Hal ini menunjukan bahwa kecerdasan intelektual bisa dijadikan variabel dalam pemahaman mata kuliah pengntar akuntansi. Hasil penelitian ini mendukung hasil penelitian yang di lakukan Inriawati Parauba (2011), dengan judul pengaruh kecerdasan intelektual, kecerdasan emosional, kecerdasan spiritual dan perilaku belajar terhadap pemahaman akuntansi. Dian khaerani (2014) dengan judul pengaruh kecerdasan intelektual, kecerdasan emosional, kecerdasan spiritual terhadap pemahaman akuntansi. Hairul anam dan lia ardillah (2016), dengan judul Pengaruh kecerdasan emosional, kecerdasan intelektual, kecerdasan spiritual dan kecerdasan sosial terhadap pemahaman akuntansi. Firdha febrianti (2017), dengan judul pengaruh kecerdasan intelektual, kecerdasan emosional, kecerdasan spiritual dan perilaku belajar terhadap tingkat pemahaman akuntansi. Pedi Riswadi dan Idhan Lakoni (2017), dengan judul pengaruh kecerdasan emosional, kecerdasan spiritual dan kecerdasan intelektual terhadap pemahaman mata kuliah pengantar akuntansi dengan perilaku belajar sebagai variabel moderasi di PTN dan PTS kota bengkulu. Akhdan Nur Said (2018), dengan judul pengaruh kecerdasan intelektual, kecerdasan emosional, dan kecerdasan spiritual terhadap sikap etis mahasiswa akuntansi.

2. Hipotesis kedua kecerdasan emosional berpengaruh secara parsial terhadap pemahaman mata kuliah pengantar akuntansi. Hal ini menunjukkan bahwa kecerdasan kecerdasan emosional bisa dijadikan variabel dalam pemahaman mata kuliah pengantar akuntansi.Hipotesis ketiga kecerdasan spiritual secara parsial berpengaruh terhadap pemahaman mata kuliah akuntansi. Hal ini menunjukkan bahwa kecerdasan spritual bisa dijadikan variabel dalam pemahaman mata kuliah pengantar akuntansi. Hasil penelitian ini mendukung hasil penelitian yang di lakukan Filia Rachmi (2012), dengan judul pengaruh kecerdasan emosional, kecerdasan spiritual, dan perilaku belajar terhadap tingkat pemahaman akuntansi. Dian khaerani (2014) dengan judul pengaruh kecerdasan intelektual, kecerdasan emosional, kecerdasan spiritual terhadap pemahaman akuntansi. Hairul anam dan lia ardillah (2016), dengan judul Pengaruh kecerdasan emosional, kecerdasan intelektual, kecerdasan spiritual dan kecerdasan sosial terhadap pemahaman akuntansi. Muhamad Rizal Satria dengan judul pengaruh kecerdasan emosional terhadap tingkat pemahaman akuntansi. Firdha febrianti (2017), dengan judul pengaruh kecerdasan intelektual, kecerdasan emosional, kecerdasan spiritual dan perilaku belajar terhadap

168 | Erwin Febriansyah; Fraternesi; Anina Safitri; Pengaruh Kecerdasan Intelektual, Kecerdasan Emosional, ... 
tingkat pemahaman akuntansi. Pedi Riswadi dan Idhan Lakoni (2017), dengan judul pengaruh kecerdasan emosional, kecerdasan spiritual dan kecerdasan intelektual terhadap pemahaman mata kuliah pengantar akuntansi dengan perilaku belajar sebagai variabel moderasi di PTN dan PTS kota bengkulu. Luhgianto (2018) Akhdan Nur Said dengan judul pengaruh kecerdasan emosional, kecerdasan spiritual terhadap pemahaman akuntansi (2018), dengan judul pengaruh kecerdasan intelektual, kecerdasan emosional, dan kecerdasan spiritual terhadap sikap etis mahasiswa akuntansi. Namun bertentangan dengan penelitian yang dilakukan oleh Inriawati Parauba dengan judul pengaruh kecerdasan intelektual, kecerdasan emosional dan kecerdasan spiritual, dan perilaku belajar terhadap pemahaman akuntansi.

3. Hipotesis ketiga kecerdasan spiritual berpengaruh terhadap pemahaman mata kuliah akuntansi. Hal ini menunjukkan bahwa kecerdasan spritual bisa dijadikan variabel dalam pemahaman mata kuliah pengantar akuntansi. Hasil penelitian ini mendukung hasil penelitian yang di lakukan Filia Rachmi (2012), dengan judul pengaruh kecerdasan emosional, kecerdasan spiritual, dan perilaku belajar terhadap tingkat pemahaman akuntansi. Dian khaerani (2014) dengan judul pengaruh kecerdasan intelektual, kecerdasan emosional, kecerdasan spiritual terhadap pemahaman akuntansi. Hairul anam dan lia ardillah (2016), dengan judul Pengaruh kecerdasan emosional, kecerdasan intelektual, kecerdasan spiritual dan kecerdasan sosial terhadap pemahaman akuntansi. Firdha febrianti (2017), dengan judul pengaruh kecerdasan intelektual, kecerdasan emosional, kecerdasan spiritual dan perilaku belajar terhadap tingkat pemahaman akuntansi. Pedi Riswadi dan Idhan Lakoni (2017), dengan judul pengaruh kecerdasan emosional, kecerdasan spiritual dan kecerdasan intelektual terhadap pemahaman mata kuliah pengantar akuntansi dengan perilaku belajar sebagai variabel moderasi di PTN dan PTS kota bengkulu. Luhgianto (2018) Akhdan Nur Said dengan judul pengaruh kecerdasan emosional, kecerdasan spiritual terhadap pemahaman akuntansi (2018), dengan judul pengaruh kecerdasan intelektual, kecerdasan emosional, dan kecerdasan spiritual terhadap sikap etis mahasiswa akuntansi. Namun bertentangan dengan penelitian yang dilakukan oleh Inriawati Parauba (2011) dengan judul pengaruh kecerdasan intelektual, kecerdasan emosional dan kecerdasan spiritual, dan perilaku belajar terhadap pemahaman akuntansi

\section{Saran}

Dalam penelitian berikutnya di masa mendatang, peneliti memberi beberapa masukan mengenai beberapa hal diantaranya:

1. Diharapkan untuk peneliti selanjutnya dapat memperhatikan instrumen penelitian tidak hanya kuesioner, melainkan menggunakan wawancara dan sebagiannya.

2. Sebaiknya untuk penelitian selanjutnya disanrankan untuk menambah variabel lain yang lebih berpengaruh terhadap pemahaman mata kuliah pengantar akuntansi misalnya prilaku belajar dan sebagiannya.

3. Sebaiknya peneliti selanjutnya memperluas cakupan objek penelitian di beberapa universitas yang memiliki jurusan akuntansi.

4. Peneliti selanjutnya yang akan datang pengambilan sampel dengan jumlah yang lebih banyak.

\section{DAFTAR PUSTAKA}

Amirin, T.( 2011). Populasi Dan SampelPenelitian 4 Ukuran Sampel Rumus Slovin. Jakarta : Erlangga

Azwar, Saifuddin. (2011). Metodepenelitian.PustakaPelajar. Yogyakarta.

Corry, Andy \& Hamid, Farid, (2012).MetodePenelitianSurvei.Jakarta :Kencana

Journal Ekombis Review, Vol. 8 No. 2 Juli 2020 page: 160 - 170| 169 
dadang, Asep (2010). Universal multikreasi, mecerdaskan IQ, EQ, SQ, Bandung : Globalindo.

Ghozali, Imam. (2013). Aplikasi Analisis Multivariate Dengan Program SPSS.

Semarang :BadanPenerbitUniversitasDiponegoro

Goleman, Daniel. (2010). Emotional Intelligence. Jakarta: PT.GramediaPustakaUtama

Gordon, Barry \& Berger Lisa, (2013). Memori Intelegen Jakarta : Erlangga

Indriantoro, Nur \& Bambang Supomo. (2010). Metode Penelitian Bisnis untuk Akuntansi dan Manajemen. Yogyakarta : BPFE.

Lupiyoadi \& Bramulya, (2015). Pratikum Metode Riset Bisnis . Jalarta : Selemba Empat.

Hidayah, N. R. (2020). Effect Of Education And Training (diklat/bimtek), Understanding Of Regional Financial Accounting Systems (Simda) On Performance Of Regional Financial Management. Bima Journal (Business, Management, \& Accounting Journal), 1(1), 61-72.

Nuraini, Maya (2010). Pengaruh Kecerdasan Emosional dan Minat Belajar Mahasiswa Akuntansi Terhadap Tingkat Pemahaman akuntansi. Gresik : jurnal BETA.

Riandi,Edi (2016) statistika penelitian ( Analisis Manual dan IBM SPSS). Yogyakarta : Penerbit Andi

Paskah, ika. (2010). "Pengaruh Kecerdasan Emosional terhadap Pemahaman Akuntansi, Jurnal Ekonomi dan Bisnis, Vol. X, No. 2.

Singarimbun, Masri. (2011). MetodePenelitianSurvay. Jakarta: PT Pustaka LP3ES Indonesia.

Sugiyono.(2016). MetodePenelitianBisnis (PendekatanKuantitatif, Kualitatif, dan $R \& D)$.Bandung :Alfabeta.

Umar, Husein (2011). MetodePenelitianUntukSkripsidanTesisBisnis, Jakarta: Raja Grafindopersada.

170 | Erwin Febriansyah; Fraternesi; Anina Safitri; Pengaruh Kecerdasan Intelektual, Kecerdasan Emosional, ... 